\title{
HASIL ANALISA KADAR NITROGEN VEGETASI PADI DENGAN DATA HYPERSPECTRAL MENGGUNAKAN INDEX VEGETASI (Studi Kasus: Karawang)
}

\author{
Rohmatul Lathifah, Bangun Muljo Sukojo \\ Jurusan Teknik Geomatika, Fakultas Teknik Sipil dan Perencanaan, Institut Teknologi Sepuluh Nopember (ITS) \\ Jl. Arief Rahman Hakim, Surabaya 60111 \\ e-mail: bangunms@gmail.com
}

\begin{abstract}
Abstrak
Vegetasi merupakan unsur utama dalam rantai makanan. Semua rantai makanan rantai utamanya dimulai dengan tanaman atau vegetasi, untuk manusia terutama di Indonesia rantai utama yang paling banyak digunakan adalah padi. Untuk memenuhi rantai utama tersebut diperlukan teknologi yang tepat untuk memonitor keberadaan vegetasi tersebut. Keberadaan vegetasi tersebut dapat dideteksi dari kadar nitrogen yang ada. Semakin besar kadar nitrogen pada vegetasi tersebut, berarti kemungkinan untuk vegetasi tersebut bertahan hidup sangat besar. Teknologi hyperspectral yang memiliki ratusan kanal mampu menyajikan spektral yang kontinu pada setiap objek yang diamati sehingga melalui data hyperspectral kadar nitrogen vegetasi dapat dideteksi dan diamati.

Pemetaan kadar nitrogen vegetasi dilakukan pada citra HyMap dengan metodeindeks vegetasi Optimized SoilAdjusted Vegetation Index (OSAVI) dan Normalized Different Nitrogen Index (NDNI) yang digunakan untuk mendeteksi kadar nitrogen yang terkandung dalam vegetasi padi dari nilai spektral yang ditampilkan.Dari pemetaan kadar nitrogen dihasilkan pembagian kelas-kelas kadar nitrogen, 8 kelas untuk hasil olahan menggunakan OSAVI dan NDNI. Kedua metode indeks vegetasi ini sama-sama memiliki korelasi yang kuat antara data hyperspectral dan data fieldspectro yaitu $\mathrm{R}=0,881843$ untuk OSAVI dan $\mathrm{R}=0,741428$ untuk NDNI. Hal ini menunjukkan pemetaan kadar nitrogen vegetasi dengan metode indeks vegetasi OSAVI dan NDNI sama-sama mempunyai korelasi yang kuat. Tetapi jika dibandingkan akan lebih baik menggunakan indeks vegetasi OSAVI.
\end{abstract}

Kata kunci- HyMap, Indeks Vegetasi, NDNI, OSAVI, Padi, Vegetasi

\section{PENDAHULUAN}

Daerah jawa barat masih didominasi oleh vegetasi. Semua jenis vegetasi merupakan unsur utama dalam rantai makanan. Vegetasi utama yang berada di daerah jawa barat adalah padi, karena jawa barat merupakan salah satu penghasil utama padi di Indonesia. Daerah utama yang menghasilkan padi adalah daerah karawang. Seiring meningkatnya konsumsi masyarakat akan beras, dan dikarenakan vegetasi merupakan rantai utama makanan maka diperlukan teknologi yang tepat guna dalam mengestimasi produktivitas padi dan jumlah vegetasi untuk mendukung tercukupinya ketersediaan pangan nasional dan pengontrolan jumlah vegetasi di kehidupan.

Status nitrogen pada tanaman adalah indikator kunci untuk mengevaluasi pertumbuhan tanaman, peningkatan hasil panen, dan perbaikan kualitas bulir atau biji-bijian, tingkat stress, dan nutrisi dari tanaman tersebut [1].

Untuk mengontrol keberadaan vegetasi dan jumlah ketersediaan padi pada khususnya maka diperlukan suatu teknologi yang dapat memberikan informasi ini. Teknologi penginderaan jauh dirasa tenologi yang cocok untuk memecahkan masalah ini, dikarenakan dapat memberikan semua informasi yang dibutuhkan. Ada dua macam penginderaan jauh yaitu multispectral dan hyperspectral.

Penginderaan jauh hyperspectral merupakan teknologi terkini dari penginderaan jauh pengembangan dari multispectral. Hyperspectral memiliki kanal yang lebih sempit dan lebih banyak dibandingkan dengan multispectral sehingga dapat memberikan informasi yang lebih akurat. Dengan memiliki ratusan bahkan ribuan kanal yang sempit, data hyperspectral mampu menyajikan informasi jauh lebih detil daripada 
data kanal lebar dalam menghitung variabelvariabel biofisik dan kimia dari tanaman [2].

Menggunakan data hyperspectral dapat diketahui kadar biokimia Nitrogen melalui pengolahan bandmath menggunakan indeks vegetasi yang kemudian dianalisis nilai spektral dan kadar nitrogennya.

Pengukuran kandungan nitrogen maupun crude protein tersebut dapat diestimasi dari data hyperspectral dari kanopi tanaman [3]. Pengolahan data citra hyperspectral untuk mendapatkan kadar nitrogen yang ada menggunakan metode indeks vegetasi Optimized Soil-Adjusted Vegetation Index (OSAVI) dan Normalized Different Nitrogen Index (NDNI). Kedua metode diatas biasanya digunakan untuk mendeteksi kadar nitrogen yang terkandung dalam vegetasi. Pembahasan ini diharapkan menghasilkan hasil yang akurat dan sesuai dalam pemetaan kadar nitrogen vegetasi terutama padi yang dominan yang kemudian untuk dianalisa seberapa besar nilai nitrogen dan persebarannya.

\section{METODOLOGI PENELITIAN}

Pada penelitian ini area studi yang digunakan adalah wilayah Kabupaten Karawang, Jawa Barat

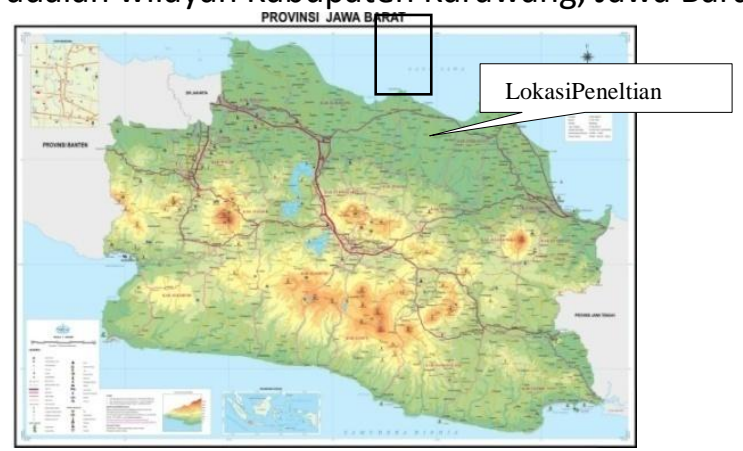

Gambar 1. Lokasi penelitian

Data yang digunakan dalam penelitian ini antara lain adalah citra HyMap Kabupaten Karawang dan Data Fieldspectro. Pada penelitian ini proses pengolahan data dapat digambarkan seperti diagram alir berikut :

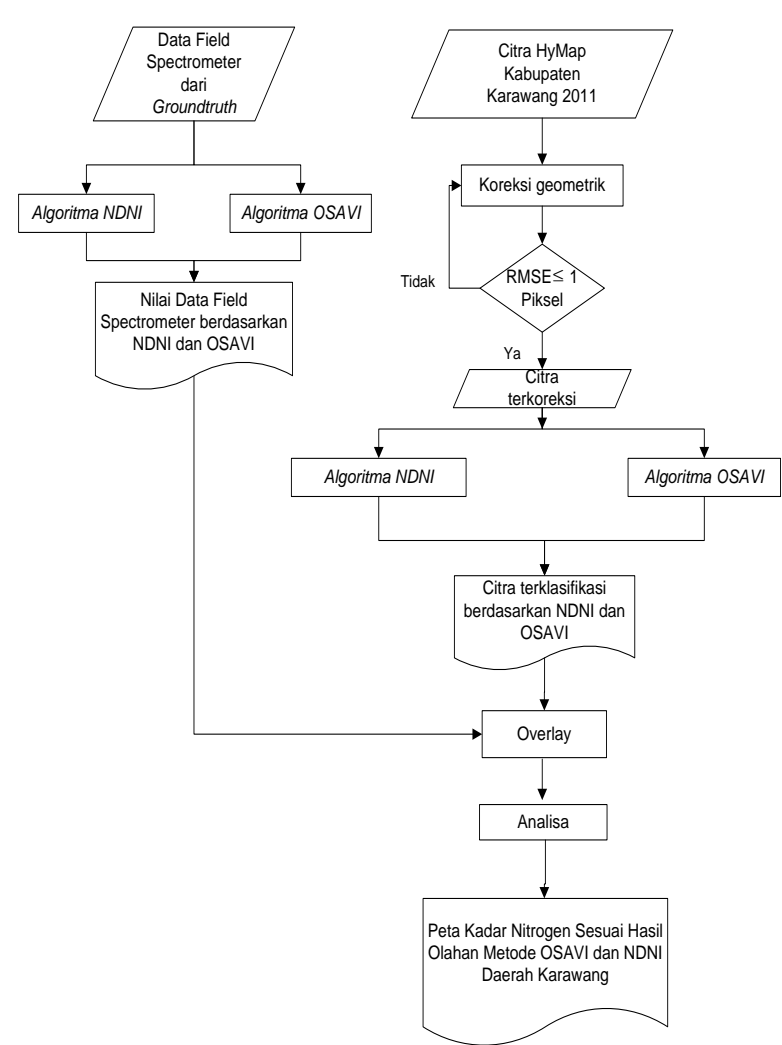

Gambar 2. Diagram Alir Pengolahan Data

Berdasarkan diagram alir diatas, secara umum penelitian ini dibagi menjadi tahapan sebagai berikut :

a. Pengolahan data airborne HyMap dengan ENVI 4.6

Mengolah dan membaca data HyMap

- Georeferencing

- Koreksi Geometrik (RMSE < 1 pixel)

- Memasukkan bandmath indeks vegetasi OSAVI dan NDNI untuk mendapatkan citra yang mengklasifikasi kadar nitrogen.

Berikut algoritma dari indeks vegetasi OSAVI dan NDNI

OSAVI $=(1+0.16) *((R 2-R 1) /(R 2+R 1+0.16))$

$\mathrm{NDNI}=\frac{\log \left(\frac{1}{\rho 1510}\right)-\log \left(\frac{1}{\rho 1680}\right)}{\log \left(\frac{1}{\rho 1510}\right)+\log \left(\frac{1}{\rho 1680}\right)}$

Keterangan:

$\mathrm{R} 1=$ panjang gelombang ke $1(680 \mathrm{~nm})$

$\mathrm{R} 2=$ panjang gelombang ke $2(800 \mathrm{~nm})$

$\rho=$ panjang gelombang $(\mathrm{nm})$

b. Pengambilan Data fieldspectrometer 
Pengambilan data fieldspectrometer dilakukan menggunakan alat fieldspectrometer 3. Reflekan kanopi daun diukur pada titik pengukuran yaitu rumpun padi dengan fieldspectrometer dari atas permukaan kanopi daun dengan ketinggian 1, 5 meter dengan sudut kemiringan $23,5^{\circ}$. Setiap pengukuran dilakukan pengulangan sebanyak minimal lima kali. Reflektan permukaan tanah atau air di sawah pada setiap QA juga diukur reflektannya. Prosedur pengukuran reflektan dapat diilustrasikan seperti pada Gambar 3.

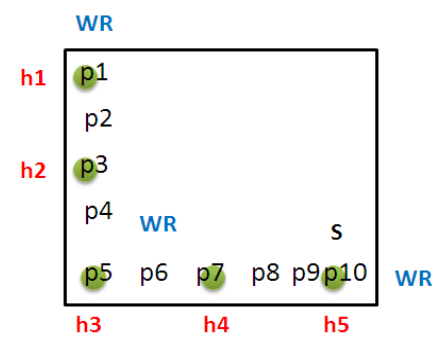

Gambar 3. Denah pengambilan data Fieldspectrometer Pada setiap Qudrat Area (QA)

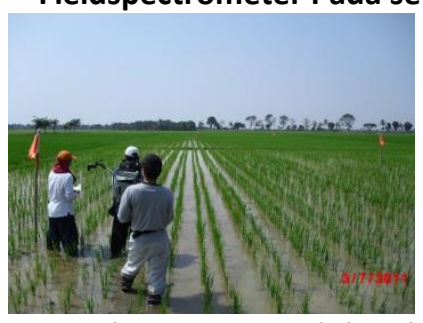

Gambar 4. Pengambilan data Fieldspectrometer

Keterangan gambar:

- p1 s/d p10 adalah lokasi pengukuran spectrometer.

- h1 s/d h5 adalah lokasi hill

- WR adalah lokasi pengukuran white reference

Pengukuran dimulai dengan mengukur reflektan white reference (WR) kemudian mengukur reflektan kanopi daun pada titik p1 s/d p5. Sebelum mengukur pada titik berikutnya dilakukan pengukuran white reference (WR) dan kemudian dilanjutkan pengukuran titik p6 s/d p10. Setelah pengukuran titik terakhir (P10) dilakukan pengukuran white reference sekali lagi, dan kemudian dilakukan pengukuran reflektan tanah atau air (S) di lokasi yang sama dengan p10. Data pengukuran dicatat dalam form dan ditandai titik yang berpasangan dengan kode hill yaitu tempat dilakukan pengukuran parameter tanaman lainnya. c. Pengolahan data fieldspectrometer

Proses pengolahan data fieldspectrometer ini dilakukan untuk menyamakan penggunakan band pada data airborne HyMap dengan data fieldspectrometer. Pada data fieldspectrometer dimasukkan rumus bandmath yang digunakan pada data airborne HyMap, maka akan menghasilkan nilai yang hampir sama untuk mendapatkan nilai kadar nitrogen.

\section{d. Overlay hasil olahan data airborne HyMap} dengan data fieldspectrometer.

Proses ini melakukan korelasi antara hasil olahan data airborne HyMap dengan hasil olahan data fieldspectrometer. Hasil korelasi $R \geq 0,60$ maka korelasi kuat dan dapat dikatakan kedua data yang digunakan mempunyai hubungan yang baik.

\section{e. Analisa}

Menganalisa hasil yang didapat dari hubungan kedua data yang digunakan dan hasil yang didapat dari hubungan kedua data.

\section{f. Pembuatan peta}

Membuat peta hasil olahan overlay kedua data dari kedua metode yang digunakan yaitu OSAVI dan NDNI. Hasilnya berupa peta persebaran kadar nitrogen vegetasi padi di daerah Karawang.

\section{HASIL DAN PEMBAHASAN}

\subsection{Hasil Koreksi Geometrik}

Koreksi geometrik dilakukan pada setiap lajur dari citra HyMap. Sebelum melakukan koreksi geometrik dilakukan proses georeferencing, setelah itu baru dilakukan proses koreksi geometrik dengan menggunakan Geometric Lookup Table (GLT) yaitu sebuah metode pengkoreksian untuk penentuan posisi geospasial pada suatu area dilihat dari lintang dan bujurnya. Data yang digunakan untuk GLT ini berformat .bsq yang saya dapat dari BPPT. Dari proses koreksi geometrik pada setiap lajur didapatkan nilai RMS Error kurang dari 1 pixel sebagai berikut :

Tabel 1. RMS Error tiap lajur

\begin{tabular}{lll}
\hline No Lajur & Jumlah GCP & RMSE \\
\hline 1 & 5 & 0.455222 \\
2 & 5 & 0.148822 \\
3 & 5 & 0.061089
\end{tabular}




\begin{tabular}{lll}
4 & 5 & 0.134704 \\
5 & 5 & 0.143967 \\
6 & 5 & 0.086194 \\
7 & 5 & 0.028612 \\
8 & 5 & 0.307975 \\
9 & 5 & 0.203117 \\
10 & 5 & 0.111994 \\
\hline
\end{tabular}

\subsection{Hasil mosaik citra}

Mosaik citra adalah proses menggabungkan dua citra atau lebih pada daerah yang bertampalan untuk memperoleh luasan area sesuai yang diinginkan. Proses ini diperlukan jika daerah yang akan dianlisa pada scene yang berbeda, tapi dengan satu syarat yaitu scene yang akan dimosaik atau digabungkan bertampalan. Syarat lainnya adalah citra yang akan dimosaik harus sudah terkoreksi.

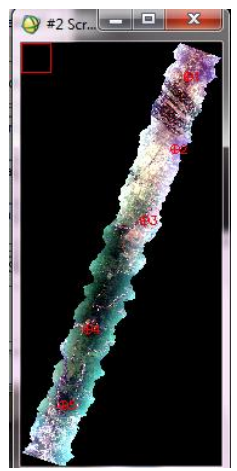

Gambar 5. Citra proses mozaicking strip 1-10 citra HyMap

3.3. Hasil Olahan Indeks Vegetasi dan Pengkelasan nilai Reflektan Nitrogen

Rentang nilai reflektan nitrogen hasil olahan menggunakan bandmath OSAVI antara nilai minimal -0.328074 sampai dengan nilai maksimal 1.060669. Sedangkan rentang nilai nitrogen hasil olahan bandmath NDNI antara nilai minimal 0.4704718 sampai dengan nilai maksimal 1.3859898 .

Tampilan hasil dari citra olahan bandmath OSAVI dan NDNI menunjukan perbedaan struktur warna sesuai dengan rentang hasil olahan bandmath. Pada citra hasil olahan bandmath OSAVI menunjukan perbedaan struktur warna yang berbeda-beda mengidikasikan perbedaan rentangnya bermacam-macam pada keseluruhan area citra, sedangkan perbedaan struktur warna citra hasil olahan menggunakan NDNI tidak begitu banyak perbedaannya hal ini mengindikasikan perbedaan rentang sedikit macamnya pada keseluruhan area citra dalam artian sebagian besar area menghasilkan nilai nitrogen yang hampir sama.

Spatial subsetting yaitu proses untuk melakukan pemotongan citra atau data citra yang tidak diperlukan, tidak penting sehingga dapat mempermudah proses komputasi berikutnya. Pengkelasan dari nilai spectral Nitrogen hasil olahan dari memasukkan bandmath OSAVI dan NDNI.hasilnya seperti berikut:

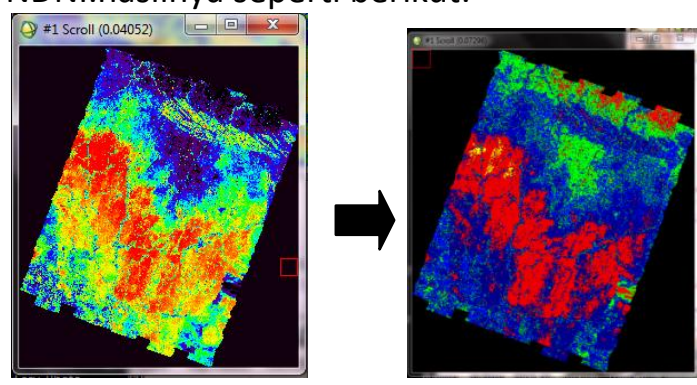

Gambar 6. Hasil Pengkelasan menggunakan ROI dari citra olahan OSAVI

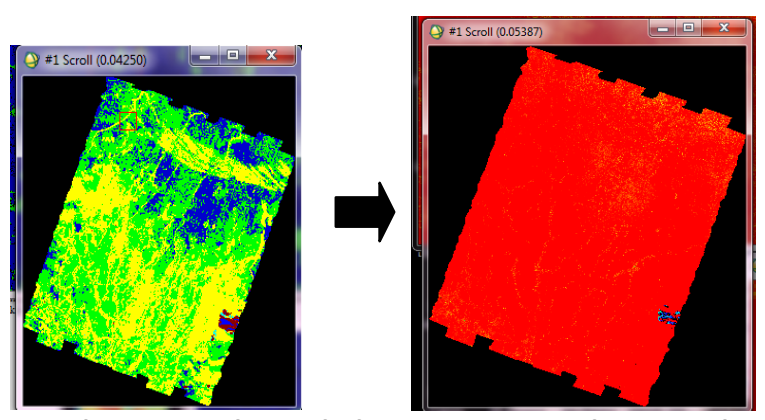

Gambar 7. Hasil Pengkelasan menggunakan ROI dari citra olahan NDNI

Dari hasil pengkelasan citra olahan OSAVI dan NDNI didapatkan delapan pengkelasan rentang nilai reflektan nitrogen yaitu $-0,4-0 ; 0,001-$ 0,$15 ; 0,15-0,3 ; 0,3-0,4 ; 0,4-0,6 ; 0,6-0,8 ; 0,8$ $-1,00 ; 1,00-1,4$.

Total piksel pengkelasan dari OSAVI adalah 25.674.421 sedangkan jumlah piksel pengkelasan NDNI adalah 23.756.809. Perbedaan jumlah ini menandakan ada beberapa unsur yang ada dibumi terdeteksi menggunakan bandmath OSAVI tetapi tidak terdeteksi menggunakan bandmath NDNI.

\subsection{Model Estimasi Nitrogen}

Dalam menghitung ground model estimasi nitrogen dilakukan dengan ekstrasi data reflektan padi Fieldspectro. Dengan 
menggunakan data Citra HyMap dicari nilai indeks vegetasi, kemudian dilakukan proses korelasi dengan data nitrogen Fieldspectro untuk mendapatkan persamaan model. Adapun hasil korelasi dari indeks vegetasi dan nitrogen sebagai berikut :

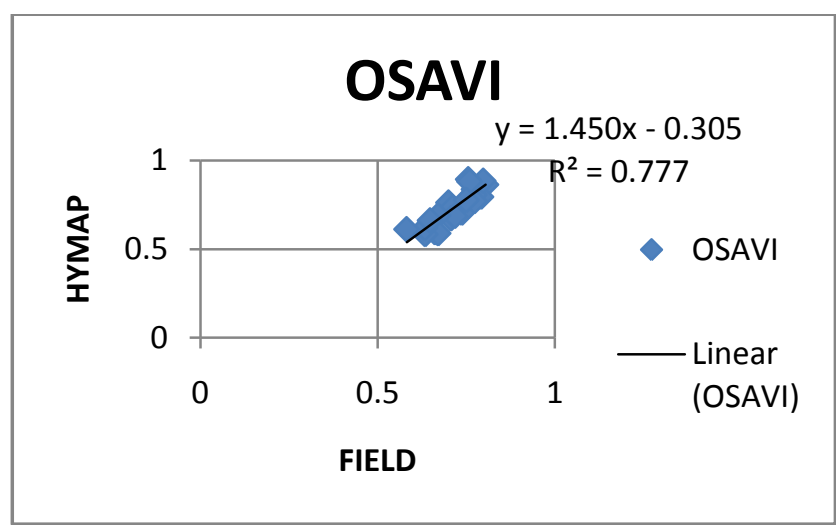

Gambar 8. Kurva hasil regresi antara indeks vegetasi OSAVI $(680,800)$ dengan data fieldspectro $(680,800)$

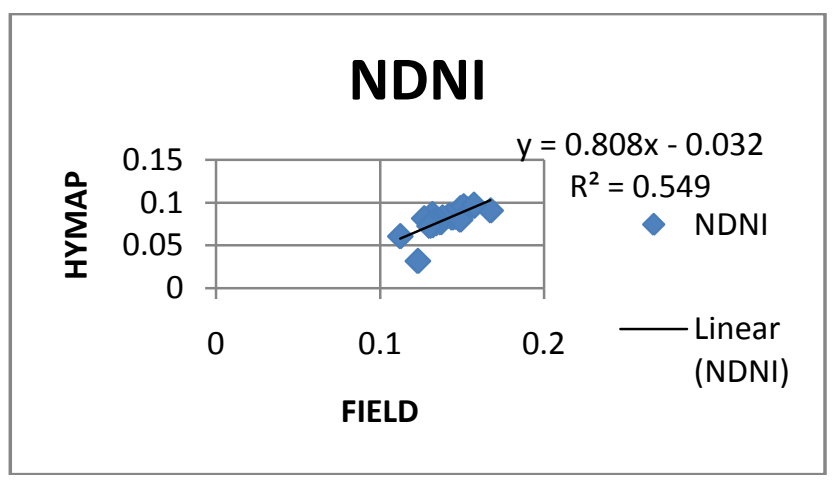

\section{Gambar 9. Kurva hasil regresi indeks vegetasi NDNI(1510,1680) dengan data fieldspectro(1510,1680).}

Dari data perhitungan regresi dapat dirangkum hasilnya dalam tebel berikut:

Tabel 2. Hasil regresi data HyMap dan data fieldspectro

\begin{tabular}{|c|c|c|c|c|c|}
\hline $\begin{array}{l}\text { Paramete } \\
r(X)\end{array}$ & Hasil Regresi & & $\begin{array}{l}\text { Koefisien } \\
\text { Determin } \\
\text { asi }\left(R^{2}\right)\end{array}$ & $\begin{array}{l}\text { Koefisien } \\
\text { Korelasi } \\
\text { (R) }\end{array}$ & RMSE \\
\hline OSAVI & $Y=1,4502 x$ & - & 0,7776 & 0,881843 & 0,7661 \\
\hline$(680,800)$ & 0,3053 & & & & \\
\hline $\begin{array}{l}\text { NDNI(151 } \\
0,1680)\end{array}$ & $\begin{array}{l}Y=0,8089 x \\
0,0329\end{array}$ & - & 0,5497 & 0,741428 & 0,7656 \\
\hline
\end{tabular}

Dari hasil korelasi antara index vegetasi data HyMap dengan data fieldspectro tanaman padi dihasilkan bahwa hasil korelasi index vegetasi data HyMap OSAVI dengan data fieldspectro lah yang lebih baik dibandingkan menggunakan index vegetasi data HyMap NDNI degan data fieldspectro.

Dari hasil regresi antara index vegetasi data HyMap dengan data fieldspectro didapatkan model terbaik yang mempunyai koefisien determinasi $\left(R^{2}\right) \geq 0,5$. Model yang memiliki koefisien determinasi baik adalah OSAVI $(680,800)$ dengan koefisien determinasi $\left(R^{2}\right)$ sebesar 0,7776 dan koefisien korelasi sebesar 0,881843. Sedangkan model NDNI menghasilkan koefisien determinasi $\left(R^{2}\right)$ sebesar 0,5497 dan koefisien korelasi sebesar 0,7411428. Dari hasil korelasi kedua index vegetasi data HyMap dengan data fieldspectro sama-sama mempunyai korelasi yang cukup kuat karena kedua nilai korelasinya $(R) \geq 0,600$. Untuk korelasi dari OSAVI memiliki hubungan yang sangat kuat karena nilai korelasi $(R) \geq 0,80$.

\subsection{Perbandingan Hasil Panjang Gelombang} Optimal Dengan Penelitian Terdahulu

Panjang gelombang optimal yang terpilih dalam studi ini adalah $680 \mathrm{~nm}(0.680 \mu \mathrm{m})$ dan 800 $\mathrm{nm}(0.800 \mu \mathrm{m})$ yaitu menggunakan metode indeks vegetasi OSAVI yang memiliki korelasi sebesar 0,881843 . Sedangkan pada penelitian terdahulu yang dilakukan oleh Dra. Nadirah, M.Sc (2009) untuk spektal indeks (pairing band) setelah melalui proses uji silang dengan metoda LOOCV(Leave One Out Cross Validation) dan 6 Fold, panjang gelombang yang optimal yaitu pada $0.735 \mu \mathrm{m}$ dan $0.790 \mu \mathrm{m}$ untuk SRSI(Simple Ratio Spectral Index), $0.715 \mu \mathrm{m}$ dan $0.790 \mu \mathrm{m}$ untuk NDSI(Normalized Difference Spectral Index), $0.715 \mu \mathrm{m}$ dan $0.790 \mu \mathrm{m}$ untuk SASI(Soil Adjusted Spectral Index), $0.715 \mu \mathrm{m}$ dan $0.790 \mu \mathrm{m}$ untuk RDSI(Renormalized Difference Spectral Index). Dari kesemua panjang gelombang yang optimal diatas dimulai pada daerah panjang gelombang Red Edge. Daerah 'red edge' merupakan daerah transisi dari absorbsi klorofil yang kuat kepada reflektansi NIR [4]. Panjang gelombang terpilih tersebut adalah informasi yang potensial untuk mengetahui status pertumbuhan dan perkembangan tanaman padi yang dapat digunakan untuk memprediksi $\mathrm{N}$ 
dengan koefisien determinasi yang besar dan RMSE yang kecil.

\subsection{Analisa Uji Korelasi Hasil Estimasi Nilai} Nitrogen

Analisis korelasi bertujuan untuk mengetahui derajat hubungan linier antara dua variabel secara kuantitatif. Korelasi searah jika nilai koefesien korelasi bernilai positif; sebaliknya jika nilai koefesien korelasi bernilai negative, korelasi disebut tidak searah.

Tabel 3. Pedoman Interpretasi Koefisien Korelasi

\begin{aligned} & \hline Interval Koefisien Tingkat Hubungan \\ & \hline $0,00-0,199$ SangatRendah \\ & $0,20-0,339$ Rendah \\ & $0,40-0,599$ Sedang \\ & \\ & $0,60-0,799$ Kuat \\ & $0,80-1,00$ SangatKuat \\ & \hline\end{aligned}

Sumber : Sugiyono, 2007

Hasil perhitungan uji korelasi pada tabel 4 tersebut termasuk korelasi sangat kuat $(0,80-$ $1,00)$ untuk OSAVI dan korelasi kuat $(0,60$ 0,799 ) untuk NDNI. Koefisien korelasi bernilai positif (+) artinya hubungan antara data HyMap dengan data fieldspectro tersebut satu arah, sehingga jika nilai spectral pada data HyMap semakin tinggi maka nilai spectral pada data Fieldspectro juga semakin tinggi, dan sebaliknya. Setelah diperoleh nilai korelasi, maka dilakukan uji signifikansi data atau uji T. Berikut hasil dari uji $\mathrm{T}$ dengan menggunakan tingkat kepercayaan $95 \%, \alpha=0,05$

Tabel 4. Uji Signifikasi Data

\begin{tabular}{llll}
\hline Parameter $(\mathrm{X})$ & Hasil Korelasi & Nilai thitung & $\begin{array}{l}\text { Nilai t } \\
\text { tabel }\end{array}$ \\
\hline OSAVI & 0,881843 & 8,569066788 & 1,721 \\
NDNI & 0,741428 & 5,063230013 & 1,721 \\
\hline
\end{tabular}

Sumber : Hasil Perhitungan

Dari hasil uji T diketahui bahwa nilai t hitung > nilai $t$ tabel, sehingga Ho ditolak, artinya hubungan antara spectral HyMap dengan spectral fieldspectro tersebut signifikan.

\subsection{Pembentukan Algoritma Airborne HyMap dari Ground Model}

Dari hasil regresi pembentukan ground model menggunakan OSAVI dan NDNI, didapatkan korelasi yang kuat dengan data fieldspectro pada ground model OSAVI yang mempunyai $R^{2} \geq 0,5$.

Tabel 5. Hasil Ground Model

\begin{tabular}{lll}
\hline $\begin{array}{l}\text { Parameter } \\
(\mathrm{X})\end{array}$ & Model & $\left(\mathrm{R}^{2}\right)$ \\
\hline OSAVI & $\mathrm{Y}=1,4502\left((1+0.16)^{*}((\mathrm{R} 800-\right.$ & 0,777 \\
$(680,800)$ & $\mathrm{R} 680) /(\mathrm{R} 800+\mathrm{R} 680+0.16)))-0,3053$ & 6 \\
$\mathrm{NDNI}(151$ & $\left.\mathrm{Y}=0,8089 \frac{\log \left(\frac{1}{\rho 1510}\right)-\log \left(\frac{1}{\rho 1680}\right)}{\log \left(\frac{1}{\rho 1510}\right)+\log \left(\frac{1}{\rho 1680}\right)}\right)$ & 0,0329 \\
$0,1680)$ & & 0,549 \\
\hline
\end{tabular}

\subsection{Peta Distribusi Nitrogen}

Hasil akhir yang didapat dari proses pengolahan algoritma ini adalah pembuatan peta distribusi kadar nitrogen di kabupaten karawang. Peta yang didapat ada dua macam, peta hasil olahan algoritma OSAVI dan peta hasil olahan algoritma NDNI

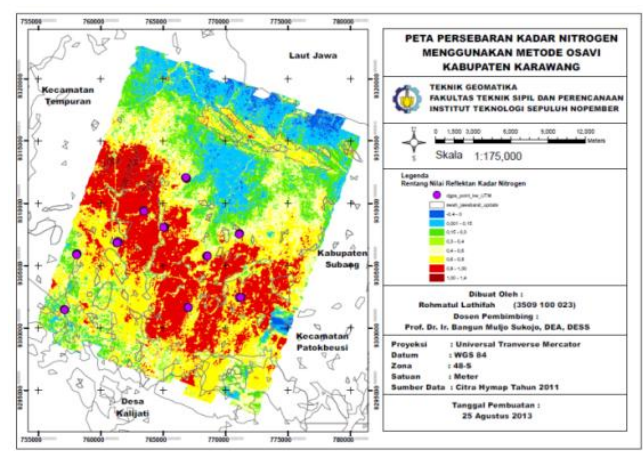

Gambar 10. Peta Persebaran Kadar Nitrogen Hasil Olahan OSAVI

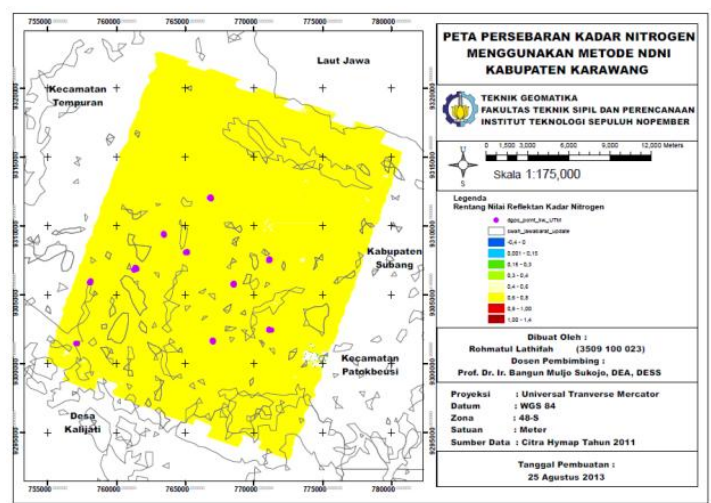

Gambar 11. Peta Persebaran Kadar Nitrogen Hasil Olahan NDNI

Dari hasil peta ini didapatkan luasan sebagai berikut:

Tabel 6. Luas area setiap kelas rentang nilai Reflektan kadar nitrogen hasil olahan OSAVI 


\begin{tabular}{lll}
\hline Kelas & $\begin{array}{l}\text { Rentang } \\
\text { Reflektan Kadar N }\end{array}$ & Nilai \\
\hline 1. & $-0,4-0$ & $5.861 .595,57$ \\
2. & $0,001-0,15$ & $48.231 .922,98$ \\
3. & $0,15-0,3$ & $57.275 .545,424$ \\
4. & $0,3-0,4$ & $30.626 .973,704$ \\
5. & $0,4-0,6$ & $61.956 .389,852$ \\
6. & $0,6-0,8$ & $134.358 .834,835$ \\
7. & $0,8-1,00$ & $126.605 .261,307$ \\
8. & $1,00-1,4$ & $2.916 .491,759$ \\
\multicolumn{2}{l}{ Total Luas } & $467.833 .015,431$ \\
\hline
\end{tabular}

Tabel 7. Luas area setiap kelas rentang nilai reflektan kadar nitrogen hasil olahan NDNI

\begin{tabular}{lll}
\hline Kelas & $\begin{array}{l}\text { Rentang Nilai } \\
\text { Reflektan Kadar N }\end{array}$ & Luas $\left(\mathrm{m}^{2}\right)$ \\
\hline 1. & $-0,4-0$ & 441,002 \\
2. & $0,001-0,15$ & 564,480 \\
3. & $0,15-0,3$ & 687,958 \\
4. & $0,3-0,4$ & 35,280 \\
5. & $0,4-0,6$ & $375.679,069$ \\
6. & $0,6-0,8$ & $465.211 .376,270$ \\
7. & $0,8-1,00$ & $3.016,444$ \\
8. & $1,00-1,4$ & 211,681 \\
Total Luas & $465.592 .012,184$ \\
\hline
\end{tabular}

Diketahui dari kedua hasil olahan Nitrogen menggunakan dua metode yang berbeda pada daerah yang sama menghasilkan kelas yang berbeda. Metode OSAVI dibagi menjadi 8 kelas rentang nilai reflektan nitrogen, sedangkan untuk NDNI dibagi menjadi 9 kelas rentang nilai nitrogen. Luasan dan rentang nilai yang dihasilkan dari olahan kedua metode pun berbeda, hal ini dikarenakan panjang gelombang yang digunakan untuk mendeteksi kadar nitrogen berbeda dan rentang yang dideteksipun berbeda. Metode OSAVI dapat mendeteksi rentang nilai nitrogen yang lebih panjang dari pada metode NDNI. Hasil rentang yang dikelaskanpun lebih bervariasi, ini menunjukkan bahwa metode OSAVI lebih baik digunakan untuk mendeteksi kadar nitrogen dibandingkan dengan metode NDNI. Hasil yang ditunjukkan OSAVI lebih baik dikarenakan panjang gelombang yang digunakan untuk mendeteksi nitrogen berada pada panjang gelombang red edge position, yaitu antara panjang gelombang $600-800 \mathrm{~nm}$. Red edge dapat berperan sebagai sistem prediksi yang cepat dan presisi terhadap parameter biokimia (kandungan N) [5]. Semua pengukuran pada Red Edge
Position kelihatannya relatif sensitif terhadap variasi kondisi atmosfir dan pengaruh air atau tanah, dan hal ini diperkuat oleh penemuanpenemuan dalam beberapa penelitian sebelumnya [6].

\subsection{Kadar Nitrogen dalam Daun}

Dalam penelitian terdahulu yang mendiagnosa penyerapan $\mathrm{N}$ dari beberapa dosis pemupukan terhadap perkembangan tanaman padi didapatkan variasi nilai statistik dari parameter biokimia (kandungan $\mathrm{N}$ daun) dengan nilai $\mathrm{N}$ minimum $0.29 \mathrm{gr} / 100 \mathrm{gr}$ dan maksimum $2.39 \mathrm{gr} / 100 \mathrm{gr}$.

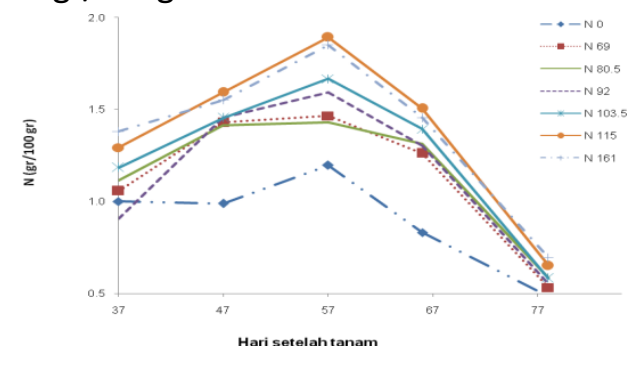

Gambar 12. Nilai kandungan N daun (gr/100gr) tanaman padi berdasarkan HST pada berbagai dosis pemupukan

\section{KESIMPULAN DAN SARAN}

Dari penelitian ini dapat diambil beberapa kesimpulan, yaitu:

Dari hasil pengolahan data untuk mengetahui kadar nitrogen dalam vegetasi dapat digunakan metode OSAVI dan NDNI.

Dari metode NDNI dan OSAVI lebih baik menggunakan metode OSAVI karena, hasil korelasi untuk OSAVI $\mathrm{R}=0,881843$ bisa diartikan nilai korelasinya sebesar $88 \%$ sedangkan nilai korelasi untuk NDNI adalah $\mathrm{R}=0,741428$ dalam artian nilai korelasi sebesar $74 \%$.

Kelas nilai reflektan kadar nitrogen yang didapatkan dari hasil olahan menggunakan kedua metode diatas adalah:

Kelas 1: $-0,4-0$

Kelas 2: $0,001-0,15$

Kelas 3: 0,15-0,3

Kelas 4: 0,3-0,4

Kelas 5: 0,4-0,6 
Kelas 6: $0,6-0,8$

Kelas 7: $0,8-1,00$

Kelas 8: $1,00-1,4$

Hasil luasan untuk kadar nitrogen menggunakan metode OSAVI adalah 467.833.015,431 $\mathrm{m}^{2}$ sedangkan untuk metode NDNI luasannya sebesar $465.592 .012,184 \mathrm{~m}^{2}$.

Dalam penelitian ini untuk metode NDNI hasil yang didapat tidak begitu bagus, hanya didapatkan kelas dengan nilai reflektan kadar nitrogen 0,6 - 0,8 dengan luasan yang mendominasi sebesar 465.211.376,270 $\mathrm{m}^{2}$ dari luasan total sebesar 465.592.012,184 $\mathrm{m}^{2}$. Hal ini dikarenakan nilai panjang gelombang yang dimasukkan untuk metode ini tidak sesuai dengan panjang gelombang untuk NDNI serta besar nilai reflektan yang dihasilkan oleh NDNI berbeda dengan metode OSAVI.

\section{DAFTAR PUSTAKA}

Knipling, E.B., (1970), "Physical and physiological basis for the reflectance of visible and nearinfrared radiation from vegetation", Remote Sensing of Environment, Vol. 1, hal. 155-159.
Wang et al. 2008. "Optimal wave kanal identification for estimation of leaf area index of paddy rice" Journal of Zheijang UniversityScience B. 9 (12) 953-963.

]Wahid, D.A., Ishiguro, E., Shimotashiro, T., Hirayama, S., Ueda, K., (2003), "Study on relationship among LAl, DW, FPAR and spectral reflectance in paddy rice", Journal of Agriculture and Meteorology., Vol. 59, NO. 1, hal. 13-21.

Lichtenthaler, H. K. (1996), "Vegetation Stress: An Introduction to the Stress Concept in Plants", Journal of Plant Physiol, Vol. 148, hal. 4-14.

Nadirah, Muljosukojo, B., Hariyanto, T., Sadly, M., Evri, M., Mulyono, S.,." Prediksi kandungan nitrogen daun padi dengan analisis pergeseran tepi kanal merah (red edge shift) data hyperspectral". Jurnal Sains dan Teknologi Indonesia (ISTI) BPPT Volume 11 Nomor 3, Desember 2009.

Baret, F., Jacquemoud, S., G., Leprieur, C., and Guyot, G., (1990), "Are spectral shifts an operational concept? Critical analysis of theoretical and experimental results", In: Proc. Airborne Geoscience Workshop, 4-5 June, Jet Propulsion Laboratory, California Institute of Technology Pasadena, CA, USA, hal. 58-71. 